\title{
25 Research Soure \\ Heterocylcic Based Cucumin: Desin, Synthesis and Anticancer Efficay Against Hela Cells
}

\section{Rana Al-Kerm}

An-Najah National University

\section{Rola Al-kerm}

An-Najah National University

Othman Hamed ( $\nabla$ ohamed@najah.edu )

An-Najah National University https://orcid.org/0000-0003-1074-2887

\section{Ashraf Sawafta}

An-Najah National University

\section{Mohammad Qneibi}

An-Najah National University

\section{Avni Berisha}

University of Prishtina: Universiteti i Prishtines Hasan Prishtina

\section{Omar Dagdage}

Sidi Mohamed Ben Abdellah University of Fes Graduate Normal School of Fes: Universite Sidi Mohamed Ben Abdellah de Fes Ecole Normale Superieure de Fes

\section{Ghaleb Adwan}

An-Najah National University

\section{Research Article}

Keywords: Curcumin, Benzodiazepine, diazole, MTT, Anticancer, HeLa cells

Posted Date: February 3rd, 2022

DOI: https://doi.org/10.21203/rs.3.rs-1298386/v1

License: (9) This work is licensed under a Creative Commons Attribution 4.0 International License.

Read Full License 


\section{Abstract}

Developing a new effective anticancer agent becomes an urgent need to overcome of current drugresistance. In this study we demonstrated that curcumin with heterocyclic moiety can function as an anticancer agent in a human. A new series of curcumin-based benzodiazepines, diazepines and diazoles were prepared using a simple one pot process. The process involved a condensation reaction of curcumin with various 1,2 diamino compounds and hydrazine. The structures of the prepared heterocycles were identified by the spectroscopic methods FT-IR, ${ }^{1} \mathrm{H}$ NMR, and ${ }^{13} \mathrm{C}$ NMR. The in vitro anticancer activities of the synthesized curcumin-based heterocycles against HeLa cancer cells were evaluated by the 3-[4,5dimethylthiazole-2-yl]-2,5-diphenyltetrazolium bromide (MTT) assay. The viability of HeLa cells was reduced in the range of $4.48-14.57 \%$ within the studied concentrations. Curcumin-based diazepine 6 showed the highest cytotoxic effect on the HeLa cells at all concentrations. it reduced the viability of the tested HeLa cells in range of $4.48 \%$ for the $400 \mu \mathrm{g} / \mathrm{ml}$ concentration to $4.95 \%$ for the $12.5 \mu \mathrm{g} / \mathrm{ml}$ concentration. Moreover, heterocyclic 6 showed the highest cytotoxic and cytostatic effect among the tested heterocyclics against Hela cells. It exhibited II $\mathrm{C}_{50}$ and a cytostatic effect of of 0.4572 and 0.08515 $\mu \mathrm{g} / \mathrm{ml}$, respectively at a nontoxic level, as the control L6 cells showed cytotoxic and cytostatic effect with $\mathrm{IC}_{50}$ values of 22.47 and $1.977 \mu \mathrm{g} / \mathrm{ml}$, respectively. This study revealed that, the prepared curcumin-based compounds exhibit a promising anticancer activity against HeLa cancer cells at a nontoxic concentration.

\section{Introduction}

Cancer is the second worldwide leading cause of death and one of the most common public health problems. World Health Organization (WHO) predicted a 70\% increasing in cancer cases by the next few decades [1]. despite the advances in the standard available therapies including chemotherapy, radiotherapy, surgery, immunotherapy and hormone therapy, Chemotherapy continues to be the most effective therapeutic option and widely used treatment for different types of malignancies. However, the side-effects associated with the cancer chemotherapy such as hair loss, fatigue, vomiting, nausea, and even death in severe cases, limit the scope of chemotherapeutic drugs. Therefore, continuous research for more efficient and less toxic cancer drug that can selectively target cancer cells with minimal or no side effects on normal cells is going on [2].

Natural plants products have traditionally been a magnificent source of pharmaceutical agents for centuries. Curcumin (1,7-bis(4-hydroxy-3-methoxyphenyl)-1,6-heptadiene-3,5-dione; diferuloylmethane) (Fig.1), is a phenolic, natural yellow to orange compound isolated from the plant Curcuma longa L. (Zingiberaceae). Curcumin has been used for centuries as a food colorant, and dietary spice in India, China, and Southeast Asia [3-8].

Curcumin and its derivatives possess numerous interesting pharmacological properties and wide variety of biological activities including anti-inflammatory, antioxidant, anti-microbial, antiviral, anti-fungal, antimalarial, anti-angiogenesis, anti-carcinogenic, antitumor, as well as medicinal applications, such as; 
their use against Alzheimer's disease and in HIV therapies [4, 5, 9-13]. Further, curcumin is non-toxic and safe even at high dosages. The non-toxicity and the natural origin of curcumin and its wide range biological activities ensure that curcumin and its derivatives are promising lead compounds in medicinal chemistry. Curcumin contains three important functional groups that mainly contribute to its biological activities, $a, \beta$-unsaturated $\beta$-diketo group; a seven carbon olefinic linker, and an ortho-methoxy phenolic hydroxy group. Structure activity-based researches have investigated that the $\alpha, \beta$-unsaturated $\beta$-diketo group is an important functionality in anticancer activity, and the length of the olefinic linker is essential for the prevention of protein aggregation in Alzheimer's disease models. Moreover, the ortho-methoxy phenolic hydroxy group and methylenic hydrogen are responsible for the antioxidant activity. Curcumin is insoluble in both water and ether but it is soluble in ethanol, acetone, chloroform, methanol, dichloromethane, and dimethylsulfoxide. It exists in enolic and $\beta$-diketonic forms. therefore, it can undergo keto-enol tautomerism that are stabilized by intra-molecular hydrogen bonding between the enolic hydrogen atom and keto carbonyl oxygen. The enol is the predominant form of curcumin in solution due to the conjugation and intramolecular hydrogen bonding that contribute to its stability $[6,7$, $9,12-14]$.

To date, a series of novel curcumin derivatives that exhibit potential synergistic anticancer activity were synthesized. The results indicated that the prepared derivatives can inhibit breast cancer stem cells growth by hindering the mediated efflux mechanism of P-glycoprotein (P-gp). Glucoside of curcumin derivatives showed higher affinity to bind with P-glycoprotein than other derivatives of curcumin. Which have reduced the breast cancer stem cells growth [15]. The anticancer effect of the combination of 5fluorouracil (5-FU) with curcumin against gastric cancer MKN45 and AGS cells was reported [16]. The results indicated that the combination of 5 -FU and curcumin $(2: 1, \mathrm{~mol} / \mathrm{mol})$ enhanced cytotoxic effect compared to curcumin or 5-FU alone and showed synergistic effect. Moreover, the combination of 5-FU and curcumin also potentiated cytotoxicity in AGS cells compared to curcumin or 5-FU alone, but the effect was moderate. Further, synthesis of new heterocyclic derivatives based on curcumin was reported [17]. The in vitro inhibition capacity of the synthesized compounds was screened in two human cancer cell lines (breast cancer (MCF-7) and hepatocellular carcinoma (HEPG2) in addition to the normal cell line (human normal melanocyte, HFB4) in comparison to the known anticancer drugs: doxorubicin and 5flurouracil. The anticancer activity results investigated that the synthesized products showed growth inhibition activity against HEPG2 cell line and MCF-7 cell line, but with varying intensities compared to the known doxorubicin and 5-flurouracil anticancer drugs [17].

In the present work, we report synthesis of new curcumin-based benzodiazepines, diazepines and diazoles via an acid catalyzed condensation cyclization reaction of curcumin with different 1,2 diamines, pyridine, pyrazine, or pyrimidine. Moreover, synthesis of hydrogenated curcumin (H-curcumin) based amine using a two-step process was also reported. The in vitro anticancer activities of the synthesized heterocycles against HeLa cancer cells were screened using the MTT colorimetric assay.

\section{Experimental}




\section{General experimental}

\section{Materials and Methods}

All chemicals used in this study were purchased from Aldrich Chemical Company and used as they were received. All prepared compounds were characterized by ${ }^{1} \mathrm{H} N M R,{ }^{13} \mathrm{C} N M R, M S / M S$ and IR spectroscopy. Nuclear Magnetic Resonance spectra were recorded on Varian Gemini 2000, $300 \mathrm{MHz}$ instruments. Infrared spectra were recorded on a Shimadzu 820 PC FT-IR spectrometer. The solvent used in the NMR was DMSO- $d_{6},{ }^{1} H$ NMR experiments were reported in $\delta$ units, parts per million (ppm) downfield from tetramethyl silane (TMS). All ${ }^{13} \mathrm{C}$ NMR spectra were reported in ppm relative to DMSO-d 6 (39.52 ppm). The reactions progress was monitored using TLC analysis performed on silica gel plates, pre-coated with Merck Kieselgel 60 F254, and visualization was done using a UV lamp. The mobile phase used was hexane: ethyl acetate (6: 4) mixture. All melting points were uncorrected and were determined in an open capillary tube. Each melting point runs were carried out at least in duplicate. The sample purifications were carried out by either crystallization or flash chromatography with silica gel (100-200) mesh.

\section{General Procedure}

\section{Preparation of curcumin-based heterocyclic compounds}

In a round-bottomed flask equipped with a condenser and a magnetic stirring bar, curcumin (1.357 mmoles, $0.5 \mathrm{~g}$ ) was dissolved in $(30.0 \mathrm{~mL})$ ethanol. The desired amine, pyridine, pyrazine, or pyrimidine ( 1.357 mmoles) was added to the curcumin solution followed by adding a few drops of the catalyst concentrated sulfuric acid. The reaction mixture was then refluxed in a paraffin oil bath until completion of the reaction ( 12 to $24 \mathrm{hr}$ ), which was monitored by TLC. The excess solvent was removed under reduced pressure using a rotary evaporator; the residue was washed with sodium bicarbonate solution (5\%), filtered, washed again with water and dried. Residual starting materials were washed out from the product by suspending the product in either diethyl ether or ethyl acetate. The products were further purified by flash chromatography or crystallization. In the preparation of compound $\mathbf{2}$ glacial acetic acid was used as a solvent [18].

\section{5,7-bis[(E)-2-(4-hydroxy-3-methoxyphenyl)ethenyl]-1H-1,4-diazepine-2,3-dicarbonitrile (2)}

A mixture of curcumin $(1.357 \mathrm{mmole}, 0.5 \mathrm{~g})$ and diaminomaleonitrile $(0.146 \mathrm{~g}, 1.357 \mathrm{mmol})$ were refluxed in glacial acetic acid $(30.0 \mathrm{~mL})$ for about $60 \mathrm{~h}$. The product was recrystallized from hexane/EtOAc $(2: 1$ by volume) to give $0.126 \mathrm{~g}$ (yield $21.1 \%$ ), $\mathrm{mp} 250-254^{\circ} \mathrm{C}$, , IR: $v_{\max } \mathrm{cm}^{-1} 3417.74(\mathrm{O}-\mathrm{H}), 3366.66(\mathrm{~N}-\mathrm{H})$, $2362.39(\mathrm{C} \equiv \mathrm{N}), 1650.55(\mathrm{C}=\mathrm{N}), 1558.32(\mathrm{C}=\mathrm{C}) .{ }^{1} \mathrm{H}-\mathrm{NMR}$ (400 MHz, DMSO-d6) 8: 3.82 (s, 6H, OCH3), 4.05 (bs, 1H, NH), $5.10(1 \mathrm{H}, \mathrm{s}), 5.41$ (bs, 2H, OH), $5.71(\mathrm{~d}, 1 \mathrm{H}, \mathrm{J}=15.1 \mathrm{~Hz}), 6.82(\mathrm{~m}, 4 \mathrm{H}), 7.03 \mathrm{~m}, 3 \mathrm{H} ; 7.25(\mathrm{~d}, 2 \mathrm{H}$, $\mathrm{J}=7.5 \mathrm{~Hz}$ ). ${ }^{13} \mathrm{C}-\mathrm{NMR}(400 \mathrm{MHz}$, DMSO-d6) $\delta: 56.1,103.6,105.0,11.3,138,1147.9$, , 115.2, 116.8, 120.2, 122.9, 124.3, 127.6, 135, 149.1, 149.4, 164.6. LC/MS [M + 1] for $\mathrm{C}_{25} \mathrm{H}_{20} \mathrm{~N}_{4} \mathrm{O}_{4}$ : Calculated 441.15, found: 441.82 
4-[(E)-2-\{2-[(E)-2-(4-hydroxy-3-methoxyphenyl)ethenyl]-5H-pyrido[2,3-b][1,4]diazepin-4-yl\}ethenyl]-2methoxyphenol (3)

A 2,3-diaminopyridine $(0.148 \mathrm{~g}, 1.357 \mathrm{mmol})$ was added to a solution of curcumin $(0.5 \mathrm{~g}, 1.357 \mathrm{mmol})$ in ethanol $(30.0 \mathrm{~mL})$, followed by adding a catalytic amount of $\mathrm{H}_{2} \mathrm{SO}_{4}(3$ drops). The produced mixture was stirred under reflux until reaction completion. The product was recrystallized from hexane/EtOAc (2:1 by volume) to give $0.35 \mathrm{~g}$ (yield 58.5\%), m.p is 118-120. IR: $v_{\max } \mathrm{cm}^{-1} 3344$ (O-H, and N-H stretching), 3022 (=C-H), 2974 (C-H, aliphatic), 1605 (C=N), 1584 (C=C, conjugated), 1389 (C-N), 1085 (C-O ether and alcohol). ${ }^{1} \mathrm{H}-\mathrm{NMR}(400 \mathrm{MHz}, \mathrm{DMSO}-\mathrm{d} 6)$ ) $8.833\left(\mathrm{~s}, 6 \mathrm{H}, \mathrm{OCH}_{3}\right), 4.0$ (bs, $\left.1 \mathrm{H}, \mathrm{NH}\right), 5.06(1 \mathrm{H}, \mathrm{d}), 5.35$ (bs, 2H, $\mathrm{OH}), 5.67(\mathrm{~d}, 1 \mathrm{H}, J=15.1 \mathrm{~Hz}), 6.80-6.98(\mathrm{~m}, 7 \mathrm{H}) ; 7.13(\mathrm{~m}, 1 \mathrm{H}), 7.26(\mathrm{~m}, 2 \mathrm{H}) ; 7.36(\mathrm{~d}, 1 \mathrm{H}, J=7.5 \mathrm{~Hz}) ; 8.12$ (d, 1H). ${ }^{13} \mathrm{C}-\mathrm{NMR}(400 \mathrm{MHz}$, DMSO-d6) $\delta: 56.1,88.69,111.9,113.0,116.8,122.9,124.0,127.6,132.6$, 135.0, 138.1, 146.6, 147.9, 149.1, 149.5, 160.0, 164.6. LC/MS [M + 1] for $\mathrm{C}_{26} \mathrm{H}_{23} \mathrm{~N}_{3} \mathrm{O}_{4}$ : Calculated 442.17, found: 442.43

\section{6,8-bis[(E)-2-(4-hydroxy-3-methoxyphenyl)ethenyl]-5H-pyrazino[2,3-b][1,4]diazepine-2,3-dicarbonitrile (4)}

A sample of 5,6-diamino-2,3-pyrazindicarbonitrile $(0.217 \mathrm{~g}, 1.357 \mathrm{mmol})$ was added to a solution of 1,7curcumin $(1.357 \mathrm{mmole}, 0.5 \mathrm{~g})$ in ethanol $(30.0 \mathrm{~mL})$ followed by adding catalytic amount of $\mathrm{H}_{2} \mathrm{SO}_{4}(3$ drops). Then the solution was refluxed until reaction completion. The product was recrystallized from hexane/EtOAc (2:1 by volume) to give $0.67 \mathrm{~g}$ (Yield 99.55\%), m.p. 206-208 ${ }^{\circ} \mathrm{C}, \mathrm{IR} v_{\max } \mathrm{cm}^{-1}: 3338.69(\mathrm{~N}-\mathrm{H})$, 3157.25 (=C-H), 2961.48 (C-H), 2231.89 (C三N stretch), 1671 (C=N), 1628.62 (C=C). ${ }^{1} \mathrm{H}-\mathrm{NMR}(400 \mathrm{MHz}$, DMSO-d6) $\delta: 3.81\left(\mathrm{~s}, 6 \mathrm{H}, \mathrm{OCH}_{3}\right), 4.1(\mathrm{bs}, 1 \mathrm{H}, \mathrm{NH}), 5.09(1 \mathrm{H}, \mathrm{s}), 5.41(\mathrm{bs}, 2 \mathrm{H}, \mathrm{OH}), 5.67(\mathrm{~d}, 1 \mathrm{H}, J=15.1 \mathrm{~Hz})$, $6.81(\mathrm{~m}, 3 \mathrm{H}), 6.83(\mathrm{~d}, 1 \mathrm{H}) ; 6.88(\mathrm{~d}, 1 \mathrm{H}) ; 6.99(\mathrm{~d}, 2 \mathrm{H}) ; 7.21(\mathrm{~d}, 2 \mathrm{H}, \quad J=7.5 \mathrm{~Hz}) .{ }^{13} \mathrm{C}-N M R(400 \mathrm{MHz}$, DMSOd6) $\delta: 56.2,112.1,117.3,122.9,127.9,131.3,135.1,124.4,137.9,148.1,149.3,149.7,154.5,147.5,155.2$, 160.2, 164.5. LC/MS [M + 1] for $\mathrm{C}_{27} \mathrm{H}_{20} \mathrm{~N}_{6} \mathrm{O}_{4}$ : Calculated 493.15, found: 493.73

\section{4-[(E)-2-\{3-bromo-8-[(E)-2-(4-hydroxy-3-methoxyphenyl)ethenyl]-5H-pyrazino[2,3-b][1,4]diazepin-6- y/3ethenyl]-2-methoxyphenol (5)}

A sample of 2, 3-diamino-5-bromopyrizine $(0.1276 \mathrm{~g}, 0.678 \mathrm{mmole})$ was added to a solution of curcumin $(0.678 \mathrm{mmole}, 0.25 \mathrm{~g})$ in ethanol $(30.0 \mathrm{~mL})$, followed by adding catalytic amount of $\mathrm{H}_{2} \mathrm{SO}_{4}$ (1 drop). Then the solution was refluxed until reaction completion. The product was recrystallized from hexane/EtOAc (2:1 by volume) to give $0.31 \mathrm{~g}$ (Yield $87.85 \%), \mathrm{mp} 88-90^{\circ} \mathrm{C}$, IR $(\mathrm{KBr}): \mathrm{max} \mathrm{cm}^{-1} 1621.33(-\mathrm{C}=\mathrm{N}), 542.15$ (C$\mathrm{Br})$, and 3384.14 (-C-N-H). ${ }^{1} \mathrm{H}-\mathrm{NMR}(400 \mathrm{MHz}, \mathrm{DMSO}-\mathrm{d} 6)$ ) $8.3 .82(\mathrm{~s}, 6 \mathrm{H}, \mathrm{OCH} 3), 3.98$ (bs, $\left.1 \mathrm{H}, \mathrm{NH}\right), 5.06(1 \mathrm{H}$, s), $5.35(\mathrm{bs}, 2 \mathrm{H}, \mathrm{OH}), 5.67(\mathrm{~d}, 1 \mathrm{H}, \mathrm{J}=15.1 \mathrm{~Hz}), 6.79(\mathrm{~m}, 2 \mathrm{H}), 6.85(\mathrm{~d}, 1 \mathrm{H}, \mathrm{J}=15.1 \mathrm{~Hz}), 6.86(\mathrm{~d}, 2 \mathrm{H}) ; 6.99(\mathrm{~d}$, 2H); $7.16(\mathrm{~d}, 2 \mathrm{H}, \quad \mathrm{J}=7.5 \mathrm{~Hz}), 7.96(\mathrm{~s}, 1 \mathrm{H}) .{ }^{13} \mathrm{C}-\mathrm{NMR}(400 \mathrm{MHz}, \mathrm{DMSO}-\mathrm{d} 6)$ ) $8: 56.2,103.1,111.5,116.4$, $121.2,122.5,124.2,135.6,139.3,147.2,149.3,150.6,159.3,164.8$. LC/MS [M + 1] for $\mathrm{C}_{25} \mathrm{H}_{21} \mathrm{BrN}_{4} \mathrm{O}_{4}$ : Calculated 521.08, found: 521.38 and 533.43 (bromine isotope). 
A 2, 3-diamino-5-bromopyridine $(0.2538 \mathrm{~g}, 1.357 \mathrm{mmol})$ was added to a solution of curcumin (1.357 mmole, $0.5 \mathrm{~g}$ ) in ethanol $(30.0 \mathrm{~mL})$, followed by the addition of concentrated $\mathrm{H}_{2} \mathrm{SO}_{4}$ (2 drops). The produced solution was then refluxed until reaction completion. The product was recrystallized from hexane/EtOAc (2:1 by volume) to give $0.34 \mathrm{~g}$ (Yield 48.14\%), $\mathrm{mp} 108-110^{\circ} \mathrm{C}, \mathrm{IR}(\mathrm{KBr}): v_{\max } \mathrm{cm}^{-1} 1623.19$ $(-\mathrm{C}=\mathrm{N}), 3374.27(-\mathrm{C}-\mathrm{NH}), 568.88(\mathrm{C}-\mathrm{Br})$, and 1030.66 (C-O ether) of $\left(-\mathrm{O}-\mathrm{CH}_{3}\right) .{ }^{1} \mathrm{H}-\mathrm{NMR}(400 \mathrm{MHz}$, DMSOd6) $\delta: 3.83\left(\mathrm{~s}, 6 \mathrm{H}, \mathrm{OCH}_{3}\right), 4.02(\mathrm{bs}, 1 \mathrm{H}, \mathrm{NH}), 5.05(1 \mathrm{H}, \mathrm{s}), 5.33(\mathrm{bs}, 2 \mathrm{H}, \mathrm{OH}), 5.68(\mathrm{~d}, 1 \mathrm{H}, \mathrm{J}=15.1 \mathrm{~Hz}), 6.81$ $(\mathrm{m}, 4 \mathrm{H}), 6.87(\mathrm{~d}, 1 \mathrm{H}, \mathrm{J}=15.1 \mathrm{~Hz}) ; 6.97(\mathrm{~d}, 2 \mathrm{H}, \mathrm{J}=7.5 \mathrm{~Hz}) ; 7.16(\mathrm{~s}, 2 \mathrm{H}), 7.67(\mathrm{~s}, 1 \mathrm{H}), 8.14(\mathrm{~s}, 1 \mathrm{H}) .{ }^{13} \mathrm{C}-\mathrm{NMR}$ (400 MHz, DMSO-d6) $\delta: 56.2,103.1,111.5,116.4,121.2,122.5,123.2,124.2,135.6,139.3,147.2,149.3$, 150.6, 159.3, 164.8. LC/MS [M + 1] for $\mathrm{C}_{26} \mathrm{H}_{22} \mathrm{BrN}_{3} \mathrm{O}_{4}$ : Calculated 521.08, found: 521.38 and 533.43 (bromine isotope).

\section{4-[(E)-2\{5-[(E)-2-(4-hydroxy-3-methoxyphenyl)ethenyl]-1-(pyrimidin-2-yl)-1H-pyrazol-3-yl\}ethenyl]-2- methoxyphenol (7)}

A 2-hydrazinopyrimidine hydrate $(0.15 \mathrm{~g}, 1.357 \mathrm{mmol})$ was added to a solution of 1,7-Bis(4-hydroxy-3methoxyphenyl)hepta-1,6-diene-3,5-dione (curcumin) (1.357 mmole, $0.5 \mathrm{~g}$ ) in ethanol (30.0 mL), followed by the addition of concentrated $\mathrm{H}_{2} \mathrm{SO}_{4}$ (2 drops). The produced solution was refluxed for about $12 \mathrm{~h}$. The product was recrystallized from hexane/EtOAc (2:1 by volume) to give $0.4 \mathrm{~g}$ (Yield $66.66 \%$ ), mp $88-90^{\circ} \mathrm{C}$, IR (KBr): $v_{\max } \mathrm{cm}^{-1} 1639.9(-\mathrm{C}=\mathrm{N}), 1061$ (C-O ether) of $\left(-\mathrm{O}-\mathrm{CH}_{3}\right)$, and $1214.80(\mathrm{~N}-\mathrm{N}) .{ }^{1} \mathrm{H}-\mathrm{NMR}(400 \mathrm{MHz}$, DMSO-d6) $\delta: 3.81(\mathrm{~s}, 6 \mathrm{H}, \mathrm{OCH} 3), 5.38(\mathrm{sb}, 2 \mathrm{H}, \mathrm{OH}), 6.76(\mathrm{~s}, 1 \mathrm{H}), 6.97(\mathrm{~m}, 6 \mathrm{H}) ; 7.12(\mathrm{~d}, 2 \mathrm{H}, \mathrm{J}=7.7 \mathrm{~Hz}), 7.18$ $(\mathrm{m}, 2 \mathrm{H}, \mathrm{J}=7.7 \mathrm{~Hz}) ; 7.68(\mathrm{~m}, 1 \mathrm{H}), 8.83(\mathrm{~d}, 2 \mathrm{H}, \mathrm{J}=7.9 \mathrm{~Hz}) .{ }^{13} \mathrm{C}-\mathrm{NMR}(400 \mathrm{MHz}, \mathrm{DMSO}-\mathrm{d} 6)$ 8: 56.2, 107.5, $109.3,116.4,116.6,118.5,122.7,123.8,130.3,131.4,147.3,147.5 .148 .1,149.3,155.7,156.6$. LC/MS [M $+1]$ for $\mathrm{C}_{25} \mathrm{H}_{22} \mathrm{~N}_{4} \mathrm{O}_{4}$ : Calculated 444.17, found: 444.67

\section{Preparation of H-Curcumin Based Amine}

\section{1,7-bis(4-hydroxy-3-methoxyphenyl)heptane-3,5-dione (8)}

A low-pressure reaction bottle was charged with a solution of curcuminoids $10.0 \mathrm{~g}$ in absolute ethanol $(100 \mathrm{ml})$ and in the presence of $\mathrm{Pd} / \mathrm{C}(0.35 \mathrm{~g})$ which was used as a heterogeneous catalyst. The bottle was attached to the low-pressure hydrogenation apparatus and evacuated, and then hydrogen was admitted to a pressure slightly above $5 \mathrm{~atm}$. The contents of the flask were shaken until absorption of hydrogen stopped (about $4 \mathrm{hrs}$ ). The catalyst was removed by filtration and ethanol was removed under vacuum to afford $4.6 \mathrm{~g}(91.8 \%)$ of pale-yellow gummy material. The gummy material was purified by flash chromatography using ethyl acetate as eluent. The prepared compound $\mathbf{8}$, was analyzed by ${ }^{1} \mathrm{H} \mathrm{NMR}$ and ${ }^{13} \mathrm{C}$ NMR. ${ }^{1} \mathrm{H}$ NMR $(300 \mathrm{MHz})\left(\mathrm{CDCl}_{3}\right): \delta=6.8(\mathrm{~d}, \mathrm{~J}=8.24,2 \mathrm{H}), 6.62(\mathrm{~d}, \mathrm{~J}=8.42=2 \mathrm{H}), 6.6(\mathrm{~s}, 2 \mathrm{H}), 5.6$ (br, 2H, OH), $5.4(\mathrm{~s}, 0.75 \mathrm{H}$, vinylic), $3.90(\mathrm{~s}, 0.5 \mathrm{H}$, diketone), $3.85(\mathrm{~s}, 6 \mathrm{H}, \mathrm{OCH} 3), 2.9(\mathrm{t}, \mathrm{J}=7.97,3 \mathrm{H}), 2.6(\mathrm{t}, \mathrm{J}$ 


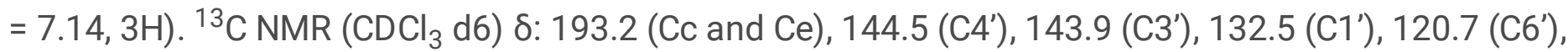

114.3 (C2'), 110.9 (C5'), 99.8 (Cd), 55.8 (OMe), 40.4 (Cb, Cf), 31.1 (Ca, Cg).

\section{4-[(4Z)-5-amino-7-(4-hydroxy-3-methoxyphenyl)-3-iminohept-4-en-1-yl]-2-methoxyphenol (9)}

A sample of 1,7-Bis(4-hydroxy-3-methoxyphenyl) hepta-1,6-diene-3,5-dione (H-curcumin, 8) (0.5 g, 12.5 $\mathrm{mL}, 1.357 \mathrm{mmol}$ ) was placed in a single-neck round bottom flask $(50 \mathrm{~mL})$ and dissolved in $2.0 \mathrm{~mL}$ ethanol. To the solution was added ammonium acetate $(0.313 \mathrm{~g}, 1.357 \mathrm{mmol})$. The produced mixture was stirred at $90^{\circ} \mathrm{C}$ until complete solvent evaporation. Then it was heated at $140^{\circ} \mathrm{C}$ until reaction completion (an hour), which was monitored by TLC. After cooling down to room temperature, it was purified by washing with water, isopropyl alcohol and diethyl ether. The purification was further completed by crystallization from ethanol/diethyl ether to give $0.3 \mathrm{~g}$ (yield $60 \%$ ) of yellow solid. Melting point is $160-163^{\circ} \mathrm{C}$, IR: $v_{\max } \mathrm{cm}^{-1} 3216.78(\mathrm{C}-\mathrm{NH}),(\mathrm{C}=\mathrm{N}), 2939.29(\mathrm{C}-\mathrm{N}), 1605.51(\mathrm{C}=\mathrm{C}), 1515.17(\mathrm{C}=\mathrm{N})$. ${ }^{1} \mathrm{HNMR}(400 \mathrm{MHz}, \mathrm{DMSO}-\mathrm{d} 6)$ ): $1.86\left(\mathrm{t}, 2 \mathrm{H}, \mathrm{CH}_{2}\right), 2.29\left(\mathrm{t}, 2 \mathrm{H}, \mathrm{CH}_{2}\right), 2.56\left(\mathrm{t}, 4 \mathrm{H}, \mathrm{CH}_{2}\right), 3.83(\mathrm{~s}, 6 \mathrm{H}, \mathrm{OCH} 3$, methyl), $3.88(\mathrm{~s}, 1 \mathrm{H}), 5.35$ (bs, 2H, OH), $6.68(\mathrm{~d}, 2 \mathrm{H}, \mathrm{CH}$ benzene), $6.71(\mathrm{~s}, 2 \mathrm{H}, \mathrm{CH}$ benzene), $6.79(\mathrm{~d}, 2 \mathrm{H}, \mathrm{CH}$ benzene) 8.56 (bs, $2 \mathrm{H}, \mathrm{NH}_{2}$ ).

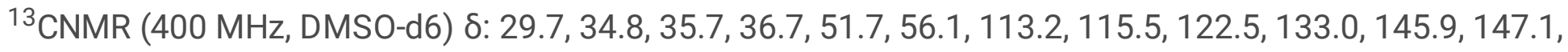
147.4, 164.6.

\section{Biological assays}

\section{Preparation of stock solutions}

Solutions of curcumin-based heterocyclics were prepared at a concentration of $400 \mu \mathrm{g}$ per $1 \mathrm{~mL}$ of dimethyl sulfoxide (DMSO) solvent and then incubated at $4{ }^{\circ} \mathrm{C}$.

Various concentrations of $(200,100,50,25$, and $12.5 \mu \mathrm{g} / \mathrm{ml})$ were then prepared using serial dilution method.

\section{Cell lines}

The human cervical cancer cell lines (HeLa cells) were obtained from the American Type Culture Collection [ATCC], Manassas, VA, USA. Were grown in RPMI medium supplemented with $10 \%$ fetal calf serum, $1 \%$ non-essential amino acid, $1 \%$ I-glutamine, $1 \%$ penicillin streptomycin and $1 \%$ amphotericin $\mathrm{B}$. All cells were grown in a humidified atmosphere of $95 \%$ air, $5 \% \mathrm{CO}_{2}$ at $37^{\circ} \mathrm{C}$, the culture medium was changed at least twice a week as needed. All chemicals used were purchased from Biological Industries except for the amphotericin B and MTT reagent from SIGMA Aldrich.

For screening experiment, the cells were grown into 12-well plates in $950 \mu \mathrm{l}$ of RPMI medium (Biological Industries, USA) containing $5 \% \mathrm{FBS}, 2 \times 10^{4}$ cells/well plating density. After that $50 \mu$ l of diverse concentrations $(400,200,100,50,25$, and $12.5 \mu \mathrm{g} / \mathrm{ml})$ of curcumin-based heterocyclics was added in 
duplicates to the prepared 12-well plates and incubated for $24 \mathrm{~h}$ at $37^{\circ} \mathrm{C}, 5 \% \mathrm{CO}_{2}, 95 \%$ air and $100 \%$ relative humidity. An inverted microscope (Labomed, USA) was used to observe the morphological changes of the cells.

\section{Cytotoxicity Assay}

Cells at $70-80 \%$ confluence were detached from culture flask by removing the culture medium then adding $0.05 \%$ trypsin- EDTA and a suspension of $100 \mu \mathrm{l}\left(2.0 \times 10^{4}\right.$ cells/well $)$ of viable cells were seeded in a 96 well plate and incubated for $24 \mathrm{~h}$ at $37^{\circ} \mathrm{C}$. After the removal of media cells were treated with $50 \mu \mathrm{l} \mathrm{stock}$ solution $(400 \mu \mathrm{g} / \mathrm{ml})$ serially diluted to reach concentrations of $(200,100,50,25$, and $12.5 \mu \mathrm{g} / \mathrm{ml})$ of curcumin-based heterocyclics, then incubated for $24 \mathrm{~h}$ at $37^{\circ} \mathrm{C}$ to perform the MTT assay.

\section{MTT assay}

The anticancer effect of curcumin-based heterocyclics against cell lines (both normal and cancer cell lines) was estimated by the 3- [4, 5- dimethylthiazole-2-yl]-2, 5-diphenyltetrazolium bromide (MTT) assay using (cell growth determination kit MTT based, Sigma). Cells $\left(2 \times 10^{4}\right.$ cells/well) for cytotoxic assay and $\left(1.0 \times 10^{4}\right.$ cells/well) for cytostatic Assaywere incubated with various concentrations of the compounds

$(400,200,100,50,25$, and $12.5 \mu \mathrm{g} / \mathrm{ml})$ in $5 \% \mathrm{CO}_{2}, 95 \%$ air and $100 \%$ relative humidity at $37^{\circ} \mathrm{C}$ for $24 \mathrm{~h}$ in an FBS-free medium. Aseptically MTT solution was added in an amount equal to $10 \%$ of the culture volume. Then cultures were returned to incubator and incubated for 4 hours. After the incubation period, the resulting MTT formazan crystals were dissolved by the addition of MTT solvent in an amount equal to the original culture volume. The addition of MTT solvent was performed after the removal and disposal of the culture fluid as HeLa cells and L6 were still attached to the culture surface. The absorbance at $570 \mathrm{~nm}$ was measured using microplate reader (Labtech, UK). The relative cell viability was determined by the amount of MTT converted to the insoluble formazan salt. The data are expressed as $v$ the mean percentage of viable cells as compared to the respective control.

\section{Results And Discussion}

In preceding studies, a non-toxic and a naturally occurring curcumin was used as a skeleton for synthesizing various heterocyclic compounds including pyrazole, diazepine, benzodiazepine, diazoles, and isoxazole $[19,20]$. The antibacterial activity and cytotoxicity of the prepared curcumin-based heterocycles were tested against gram-positive and gram-negative bacteria. Some showed excellent antibacterial activities against the tested strains. Moreover, some of the prepared diazepines showed a synergistic effect with ampicillin antibiotic. The results indicated that the curcumin-based heterocycles are promising for designing a potentially active anticancer agent. The compound selected for this purpose are curcumin with heterocyclic moiety, since as shown in Figure 1, they have the functionalities that make ideal for this purpose. 
Based on these results and to extend the work for development of curcumin-based reagents with better bioactivity. The anticancer activities of the prepared heterocycles against HeLa cancer cells were evaluated. Unsophisticated and convenient synthetic methods were employed in this work in preparation of benzodiazepines, diazepines, diazoles, and amines via condensation cyclization of curcumin with various 1,2 diamino and hydrazine compounds. Schemes I, II and III show a summary of the prepared compounds structures and reaction conditions.

In the preparation of curcumin-based benzodiazepines, diazepines and diazole, ethanol was used as a solvent and $\mathrm{H}_{2} \mathrm{SO}_{4}$ as a catalyst. However, in the condensation reaction for making diazepine 2 , curcumin was refluxed with diaminomaleonitrile in a glacial acetic acid, which was performed as a catalyst and a solvent. The reaction progress was monitored by TLC. Curcumin-based benzodiazepines, diazepines $\mathbf{2 , 3}$, 4,5 , and $\mathbf{6}$ required more reflux time than diazole 7. Two methods were employed in purification of the prepared heterocycles, either column chromatography or crystallization. The purified products were analyzed by FT-IR, ${ }^{1} \mathrm{H}$ NMR, and ${ }^{13} \mathrm{C}$ NMR; The detailed descriptions of all the procedures and of the final analytical characterization are summarized in the experimental part. The yield was quantitative for derivatives, it ranged between $21 \%$ and $99 \%$.

Hydrogenated curcumin ( $\mathrm{H}$-Curcumin-based amine, 9) was prepared in a two-step process, as shown in (scheme III). The first step involved the hydrogenation of curcumin 1 using a hydrogenation apparatus charged, absolute ethanol was used as a solvent and $\mathrm{Pd} / \mathrm{C}$ was the catalyst. The pale-yellow gummy product $\mathbf{8}$ was purified by flash chromatography using ethyl acetate as eluent and analyzed by FT-IR, ${ }^{1} \mathrm{H}$ NMR, and ${ }^{13} \mathrm{C}$ NMR as described in the experimental part.

The second step involves condensation reaction of amination of $\mathrm{H}$-Curcumin $\mathbf{8}$ with Ammonium acetate as shown in (scheme III). The progress of reaction was monitored using TLC. The synthesized product was purified as previously described in the experimental part. The structure of compound $\mathbf{9}$ was identified by FT-IR, ${ }^{1} \mathrm{H}$ NMR, and ${ }^{13} \mathrm{C}$ NMR.

\section{Anticancer activity}

Curcumin and its derivatives have been known to have a wide variety of therapeutic effects, ranging from anti-inflammatory, chemo-preventive, anti-proliferative, and anti-metastatic. In this work a novel set curcumin-based heterocyclics were screened for their anti-tumor effect against HeLa cells. The in vitro cytotoxic and cytostatic effect of the prepared heterocyclics were evaluated using MTT test.

\section{Cytotoxic effect of the curcumin-based heterocyclics}

Cells $\left(2 \times 10^{4}\right.$ cells/well) with $40-50 \%$ confluence were seeded on 96 -well plate, the cells were then treated with different concentrations of the prepared curcumin-based heterocyclics $(400,200,100,50,25$, and $12.5 \mu \mathrm{g} / \mathrm{ml}$ ) and incubated for 24 hours. 
MTT assay was used to determine the cell viability by adding MTT solution to the plate and incubated for four hours, after that the isopropyl alcohol was added and incubated in dark for 15 minutes. The microplate reader (Labtech, UK) was used to measure the absorbance at $570 \mathrm{~nm}$.

\section{Cytotoxic effect of the curcumin-based heterocyclics on HeLa cells}

The in vitro anticancer activities of a novel set of curcumin-based benzodiazepine, diazepines, diazoles, and $\mathrm{H}$-curcumin based amine against HeLa cancer cell were evaluated. The results indicate that the prepared curcumin-based heterocyclics have varying cytotoxic effect on the HeLa cells at different concentrations. The viability of HeLa cells has reduced in the range of $4.48-14.57 \%$ within the studied concentration range as shown in (Table 1). In general, cells growth was decreased as the concentration of the prepared curcumin-based heterocyclics increased (Fig. 2).

Series 1: compound 2, series 2: compound 3 , series 3 : compound 4 , series 4 : compound 5 series 5 : compound 6, series 6: compound 7, series 7: compound 9.

\section{Table 1: In vitro effects of curcumin-based heterocyclics on the viability of HeLa cells at different concentrations $(\mu \mathrm{g} / \mathrm{ml})$.}

\begin{tabular}{|lllllll|}
\hline Curcumin Derivatives & \multicolumn{7}{c|}{ Concentration $(\boldsymbol{\mu g} / \mathrm{ml})$} \\
\cline { 2 - 7 } & 400 & 200 & 100 & 50 & 25 & 12.5 \\
\hline $\mathbf{2}$ & $4.84 \%$ & $4.95 \%$ & $5.07 \%$ & $5.076 \%$ & $5.096 \%$ & $6.96 \%$ \\
\hline $\mathbf{3}$ & $4.78 \%$ & $4.84 \%$ & $4.88 \%$ & $5.07 \%$ & $5.44 \%$ & $5.59 \%$ \\
\hline $\mathbf{4}$ & $4.72 \%$ & $4.84 \%$ & $5.07 \%$ & $5.19 \%$ & $6.32 \%$ & $6.73 \%$ \\
\hline $\mathbf{5}$ & $4.63 \%$ & $4.75 \%$ & $4.82 \%$ & $4.88 \%$ & $5.12 \%$ & $5.9 \%$ \\
\hline $\mathbf{6}$ & $4.48 \%$ & $4.6 \%$ & $4.7 \%$ & $4.72 \%$ & $4.84 \%$ & $4.95 \%$ \\
\hline $\mathbf{7}$ & $4.71 \%$ & $4.84 \%$ & $4.9 \%$ & $5.95 \%$ & $6.02 \%$ & $8.31 \%$ \\
\hline $\mathbf{9}$ & $5.43 \%$ & $6.37 \%$ & $7.08 \%$ & $9.07 \%$ & $11.28 \%$ & $14.57 \%$ \\
\hline
\end{tabular}

Curcumin-based benzodiazepine and diazepines $\mathbf{2}, \mathbf{3}, \mathbf{4}, \mathbf{5}$, and $\mathbf{6}$ showed higher potency on HeLa cancer cells than the other tested compounds $\mathbf{7}$ and $\mathbf{9}$. The viability of HeLa cells that were treated with benzodiazepine and diazepines $2,3,4,5$, and 6 was reduced in the range of $4.48-6.73 \%$. Curcumin-based diazepines 6 showed the highest cytotoxic effect on the HeLa cells at all concentrations. it reduced the viability of the tested HeLa cells in range of $4.48 \%$ for the $400 \mu \mathrm{g} / \mathrm{ml}$ concentration to $4.95 \%$ for the 12.5 $\mu \mathrm{g} / \mathrm{ml}$ concentration. Among the prepared curcumin-based benzodiazepine $\mathbf{3}$ and $\mathbf{5}$ are more effective against HeLa cancer cells than 4. As they reduced the viability of the tested HeLa cells in range of $4.78 \%$ and $4.63 \%$ for the $400 \mu \mathrm{g} / \mathrm{ml}$ concentration to $5.95 \%$ and $5.9 \%$ for the $12.5 \mu \mathrm{g} / \mathrm{ml}$ concentration for 3 and $\mathbf{5}$, respectively. $\mathrm{IC}_{50}$ of the prepared heterocyclestested on HeLa cancer cells were; compound 2 
0.2490, compound 3 0.6811, compound 4 4.454, compound 52.120 , compound 60.4572 , and compound 7 1.245. (Fig. 3, Fig.4, Table 2) The lines represent the mean of three independent experiments carried out in triplicates.

\section{Table 2: Cytotoxic and cytostatic effect of the prepared heterocycles on HeLa cancer cells and L6 Cells (normal cells)}

\begin{tabular}{|c|c|c|c|c|c|c|c|c|}
\hline & Curcumin & 2 & 3 & 4 & 5 & 6 & 7 & 9 \\
\hline $\begin{array}{l}\text { Hela } \\
\text { Cytotoxic }\end{array}$ & 12.46 & 0.2490 & 0.6811 & 4.454 & 2.120 & 0.4572 & 1.245 & 6.164 \\
\hline $\begin{array}{l}\text { Hela } \\
\text { Cytostatic }\end{array}$ & 10.21 & $\tilde{0} .1036$ & 0.3536 & 2.947 & 0.3425 & $\tilde{0} .08515$ & 0.5230 & 0.8659 \\
\hline L6 Cytotoxic & 12.7 & 12.48 & 13.76 & 9.307 & 10.75 & 22.47 & 25.00 & 15.61 \\
\hline L6 Cytostatic & 10.5 & 3.947 & 1.120 & 4.088 & 0.9463 & 1.977 & 1.202 & 1.090 \\
\hline
\end{tabular}

Cytotoxic effect of the prepared heterocycles on L6 Cells (normal cells)

Results show that most of the prepared heterocycles have a cytotoxic effect on L6 cells at concentrations higher than $12.5 \mu \mathrm{g} / \mathrm{ml}$. IC $I_{50}$ of the prepared heterocycles were; compound 2 12.43, compound 3 13.76, compound 4 9.307, compound 5 10.75, compound 6 22.47, compound 725.00 and compound 915.61 (Fig. 5, Table 2). The lines represent the mean of three independent experiments carried out in triplicates.

Results of L6 cells showed that all the tested curcumin-based heterocyclics exhibited cytotoxic and cytostatic effects in a dose-dependent manner as presented in Figure 5, Figure 6, and Table 2. Most of curcumin-based benzodiazepine and diazepines 2, 3, and 6 induced higher cytotoxic and cytostatic effects compared to curcumin-based diazole 7 and H-curcumin-based amine 9 at the same concentrations. Heterocyclic 2 exhibited cytotoxic and cytostatic effect against Hela cells with $\mathrm{IC}_{50}$ values of 0.2490 and $\sim 0.1036 \mu \mathrm{g} / \mathrm{ml}$ respectively at nontoxic levels as the control L6 cells showed cytotoxic and cytostatic effect with $\mathrm{IC}_{50}$ values of 12.48 and $3.947 \mu \mathrm{g} / \mathrm{ml}$ respectively. Heterocyclic 3 exhibited cytotoxic and cytostatic effect against Hela cells with $\mathrm{IC}_{50}$ values of 0.6811 and $0.3536 \mu \mathrm{g} / \mathrm{ml}$ respectively at nontoxic levels as the control L6 cells showed cytotoxic and cytostatic effect with $\mathrm{IC}_{50}$ values of 13.76 and $1.120 \mu \mathrm{g} / \mathrm{ml}$ respectively. Heterocyclic 4 exhibited cytotoxic and cytostatic effect against Hela cells with $\mathrm{IC}_{50}$ values of 4.454 and $2.947 \mu \mathrm{g} / \mathrm{ml}$ respectively at nontoxic levels as the control L6 cells showed cytotoxic and cytostatic effect with $\mathrm{IC}_{50}$ values of 2.947 and $4.088 \mu \mathrm{g} / \mathrm{ml}$ respectively. Heterocyclic $\mathbf{5}$ exhibited cytotoxic and cytostatic effect against Hela cells with $\mathrm{IC}_{50}$ values of 2.120 and $0.3425 \mu \mathrm{g} / \mathrm{ml}$ respectively at nontoxic levels as the control L6 cells showed cytotoxic and cytostatic effect with $\mathrm{IC}_{50}$ values of 10.75 and $0.9463 \mu \mathrm{g} / \mathrm{ml}$ respectively. Heterocyclic 6 exhibited cytotoxic and cytostatic effect against Hela cells with $\mathrm{IC}_{50}$ values of 0.4572 and $\sim 0.08515 \mu \mathrm{g} / \mathrm{ml}$ 
respectively at nontoxic levels as the control L6 cells showed cytotoxic and cytostatic effect with $\mathrm{IC}_{50}$ values of 22.47 and $1.977 \mu \mathrm{g} / \mathrm{ml}$ respectively.

In general, heterocyclic $\mathbf{6}$ showed the highest cytotoxic and cytostatic effect among the tested heterocyclics against Hela cells at same concentration. It exhibited $\mathrm{IC}_{50}$ values of 0.4572 and $\sim 0.08515$ $\mu \mathrm{g} / \mathrm{ml}$ respectively at nontoxic levels as the control L6 cells showed cytotoxic and cytostatic effect with $\mathrm{IC}_{50}$ values of 22.47 and $1.977 \mu \mathrm{g} / \mathrm{ml}$ respectively.

Curcumin-based diazole 7 showed the lowest effect on the HeLa cells. It showed lower effect than curcumin-based benzodiazepine and diazepines $\mathbf{2}, \mathbf{3}, \mathbf{4}, \mathbf{5}$, and $\mathbf{6}$. Compound $\mathbf{7}$ reduced the viability of the tested HeLa cells in range of $4.71 \%$ for the $400 \mu \mathrm{g} / \mathrm{ml}$ concentration to $8.31 \%$ for the $12.5 \mu \mathrm{g} / \mathrm{ml}$ concentration. curcumin-based diazole 7 exhibited cytotoxic and cytostatic effect against Hela cells with $I C_{50}$ values of 1.245 and $0.5230 \mu \mathrm{g} / \mathrm{ml}$ respectively at nontoxic levels as the control L6 cells showed cytotoxic and cytostatic effect with $\mathrm{IC}_{50}$ values of 25.00 and $1.202 \mu \mathrm{g} / \mathrm{ml}$ respectively. The anticancer activities shown above could explained by structure activity relationship. Curcumin with benzodiazepine moiety $\mathbf{6}$ showed the highest activity. The presence of the hetero atom and nitrogen in addition to bromine gives this molecule the ability to accommodate well into the binding site and interact with the receptor site of the cancer cells and interact through $\mathrm{H}$-bonding with functional groups present in the receptor site. As more substituents are introduced in the benzodiazepine ring the activity decreases as the case with compound $\mathbf{4}$, in this case the steric factor effect becomes the predominant factor that tend to reduce the interaction with the receptor sites and thus the potency drops.

On the other hand, H-curcumin amine 9 showed the lowest cytotoxic effect on the HeLa cells at all concentrations among the prepared heterocyclics. It reduced the viability of the tested HeLa cells in range of $5.43 \%$ for the $400 \mu \mathrm{g} \mathrm{/ml}$ concentration to $14.57 \%$ for the $12.5 \mu \mathrm{g} / \mathrm{ml}$ concentration. H-curcuminbased amine 9 exhibited cytotoxic and cytostatic effect against Hela cells with $\mathrm{IC}_{50}$ values of 6.164 and $0.8659 \mu \mathrm{g} / \mathrm{ml}$ respectively at nontoxic levels as the control L6 cells showed cytotoxic and cytostatic effect with $\mathrm{IC}_{50}$ values of 15.61 and $1.090 \mu \mathrm{g} / \mathrm{ml}$ respectively.

The reason for the low bioactivity of compound $\mathbf{9}$ could be due to the loss of the olefinic part of curcumin due to hydrogenation. As mentioned in the introduction this functionality is important functionality in anticancer activity. For comparison purpose we tried converting curcumin to curcumin amine as shown in Fig 7 but the effort was unsuccessful.

\section{Conclusion}

The in vitro anticancer activities of a novel synthesized set of heterocycles against HeLa cancer cells and normal muscle cells L6 as a control were evaluated. The results indicated that all the tested curcuminbased heterocyclics have varying cytotoxic effect on the HeLa cells at different concentrations. The viability of HeLa cells was reduced in the range of $4.48-14.57 \%$ within the studied concentration. Cell growth was decreased as the concentration of the prepared curcumin-based heterocyclics increased. 
Curcumin-based benzodiazepine and diazepines showed higher potency on HeLa cancer cells than the other tested heterocyclics. The viability of HeLa cells that were treated with benzodiazepine and diazepines was reduced in the range of 4.48- 6.73\%. On the other hand, curcumin-based diazepine 6 showed the highest cytotoxic effect on the HeLa cells at all concentrations. it reduced the viability of the tested HeLa cells in range of $4.48 \%$ for the $400 \mu \mathrm{g} / \mathrm{ml}$ concentration to $4.95 \%$ for the $12.5 \mu \mathrm{g} / \mathrm{ml}$ concentration. Heterocyclic 6 showed the highest cytotoxic and cytostatic effect among the tested heterocyclics against Hela cells at same concentration. It exhibited IC ${ }_{50}$ values of 0.4572 and $\sim 0.08515$ $\mu \mathrm{g} / \mathrm{ml}$ respectively at nontoxic levels as the control L6 cells showed cytotoxic and cytostatic effect with $\mathrm{IC}_{50}$ values of 22.47 and $1.977 \mu \mathrm{g} / \mathrm{ml}$ respectively. $\mathrm{H}$-curcumin-based amine 9 showed the lowest cytotoxic effect on the HeLa cells at all concentrations among the prepared heterocyclics. It reduced the viability of the tested HeLa cells in range of $5.43 \%$ for the $400 \mu \mathrm{g} / \mathrm{ml}$ concentration to $14.57 \%$ for the $12.5 \mu \mathrm{g} / \mathrm{ml}$ concentration. Strictly speaking all the synthesized curcumin-based compounds exhibited promising anticancer activity against HeLa cancer cells, which indicates that these compounds have anticancer effect at nontoxic concentrations.

\section{References}

1. Sawant S, Ranjita Shegokar R (2014) Cancer research and therapy: Where are we today? JCTO 4:02048. DOI: 10.14319/ijcto.0204.8

2. Aslam MS, Naveed S, Ahmed A, Abbas Z, Gull I, Athar MA (2014) Side Effects of Chemotherapy in Cancer Patients and Evaluation of Patients Opinion about Starvation Based Differential Chemotherapy. J Cancer Ther 5:817-822

3. Priyadarsini KI (2013) Chemical and Structural Features Influencing the Biological Activity of Curcumin. Curr Pharm Des 19:2093-2100

4. Fang J, Lu J, Holmgren A (2005) Thioredoxin Reductase Is Irreversibly Modified by Curcumin. J Biol Chem 280:25284-25290

5. Borik RM, Fawzy NM, Abu-Bakr SM, Aly MS, Design (2018) Synthesis, Anticancer Evaluation and Docking Studies of Novel Heterocyclic Derivatives Obtained via Reactions Involving Curcumin. Molecules 23:1398. doi:10.3390/molecules23061398

6. Ciochina R, Savella C, Cote B, Chang D, Rao D (2014) Synthesis and Characterization of New Curcumin Derivatives as Potential Chemotherapeutic and Antioxidant Agents. Drug Dev Res 75:8896

7. Ahmed M, Abdul Qadir M, Shafiq MI, Muddassar M, Abdul Hameed A, Arshad MN, Asiri AM (2017) Curcumin: Synthesis optimization and in silico interaction with cyclin dependent kinase. Acta Pharm. ; 67:385-395

8. Sato T, Hotsumi M, Makabe K, Konno H (2018) Design, synthesis and evaluation of curcumin-based fluorescent probes to detect A $\beta$ fibrils. Bioorganic Med Chem Lett 28:3520-3525

9. Li Q, Chen J, Luo S, Xu J, Huang Q, Liu T (2015) Synthesis and assessment of the antioxidant and antitumor properties of asymmetric curcumin analogues. Eur J Med Chem 93:461-469. doi: 
10.1016/j.ejmech.2015.02.005

10. Ma'mani L, Nikzad S, Kheiri-manjili H, al-Mussawi S, Saeedi M, Askarlou S, Foroumadi A, Shafiee A (2014) Curcumin-Loaded guanidine functionalized PEGylated I3ad mesoporous silica nanoparticles KIT-6: practical strategy for the breast cancer therapy. Eur J Med Chem 83:646-654. doi:

10.1016/j.ejmech.2014.06.069

11. Ding L, Ma S, Lou H, Sun L, Ji M (2015) Synthesis and Biological Evaluation of Curcumin Derivatives with Water-Soluble Groups as Potential Antitumor Agents: An in Vitro Investigation Using Tumor Cell Lines. Molecules 20:21501-21514. doi:10.3390/molecules201219772

12. Mishra S, Patel S, Halpani CG (2018) Recent Updates in Curcumin Pyrazole and Isoxazole Derivatives: Synthesis and Biological Application. Chem. Biodiversity. doi:10.1002/cbdv.201800366

13. Ramya PV, Guntuku L, Angapelly S, Digwal CS, Lakshmi UJ, Sigalapalli DK, Babu BN, Naidu VG, Kamal A (2018) Synthesis and biological evaluation of curcumin inspired imidazo[1,2-a]pyridine analogues as tubulin polymerization inhibitors. Eur J Med Chem 143:216-231. doi:

10.1016/j.ejmech.2017.11.010

14. Khor PY, Aluwi MF, Rullah K, Lam KW (2019) Insights on the synthesis of asymmetric curcumin derivatives and their biological activities. Eur J Med Chem 183:111704. doi: https://doi.org/10.1016/j.ejmech.2019.111704

15. Khwaza V, Aderibigbe BA (2019) Curcumin and Its Derivatives as Potential Therapeutic Agents in Prostate, Colon and Breast Cancers. Molecules 24:4386

16. Yang H, Huang S, Wei Y, Cao S, Pi C, Feng T, Liang J, Zhao L, Ren G (2017) Curcumin Enhances the Anticancer Effect Of 5-fluorouracil against Gastric Cancer through Down-Regulation of COX-2 and NF- kB Signaling Pathways. J Cancer 8:3697-3706

17. Borik RM, Fawzy NM, Abu-Bakr SH, Aly MS, Design (2018) Synthesis, Anticancer Evaluation and Docking Studies of Novel Heterocyclic Derivatives Obtained via Reactions Involving Curcumin. Molecules 23:1398. doi:10.3390/molecules23061398

18. Hamed O, Fares O, Taleeb S, Adwan G, Saadeh H, Jodeh S, Algarra M (2019) New Insights Towards 1,4-Benzodiazepines from Curcumin. Design, Synthesis and Antimicrobial Activities. Med Chem 15:1-12. DOI: 10.4172/2161-0444.1000533

19. Hamed OA, Mehdawi N, Abu Taha A, Hamed EM, Al-Nuri MA, Hussein AS (2013) Synthesis and Antibacterial Activity of Novel Curcumin Derivatives Containing Heterocyclic Moiety. Iran J Pharm Sci 12(1):47-56

20. Qneibi M, Hamed O, Jaradat N, Hawash M, Al-Kerm R, Al-Kerm R, Sobuh S, Tarazi S (2021) The AMPA receptor biophysical gating properties and binding site: Focus on novel curcumin-based diazepines as non-competitive antagonists. Bioorg Chem 116:105406.

https://doi.org/10.1016/j.bioorg.2021.105406

\section{Scheme}


Scheme 1,2 and 3 is available in supplementary section.

\section{Figures}

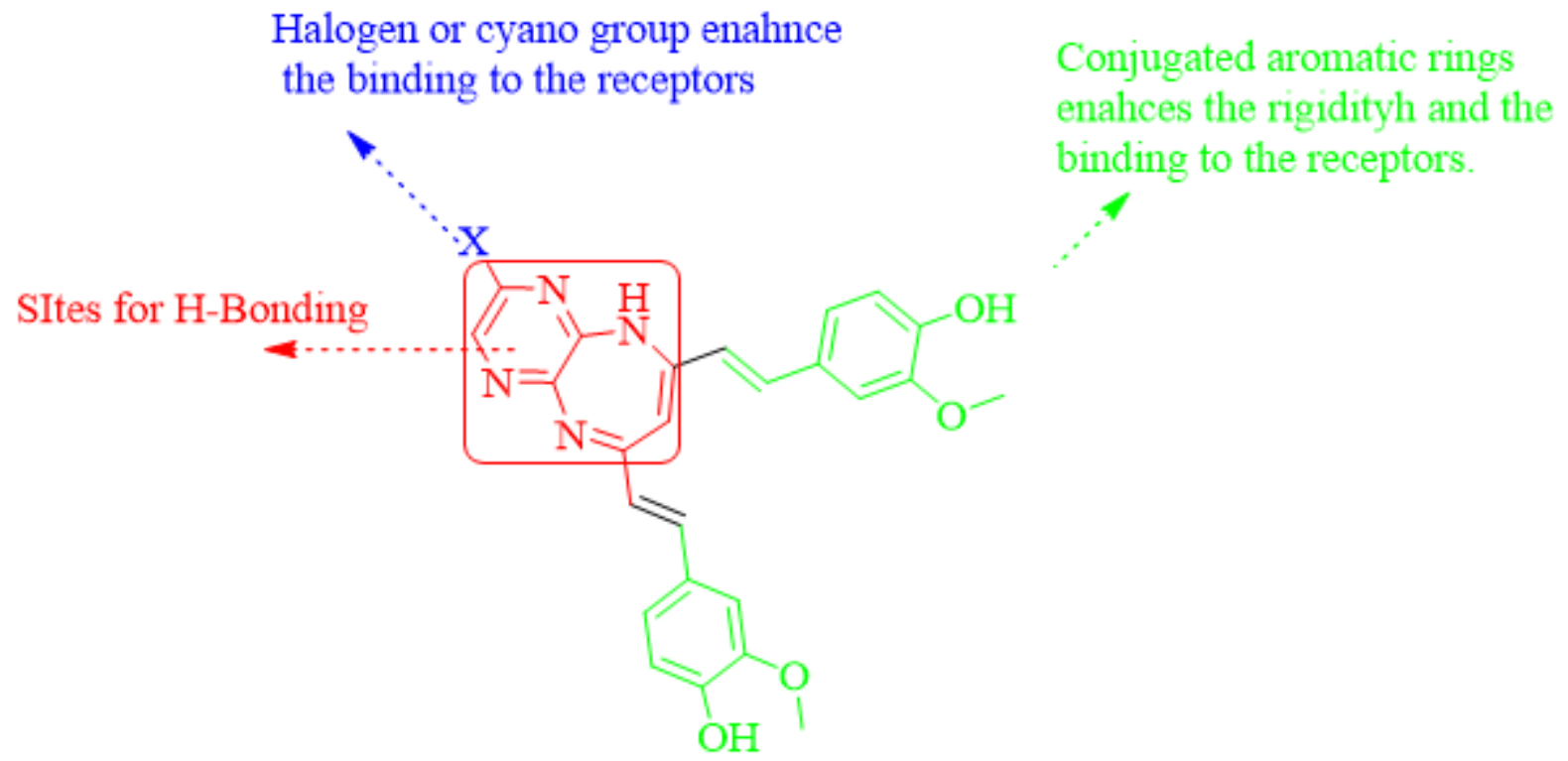

\section{Figure 1}

Functional groups present in curcumin bases heterocycles

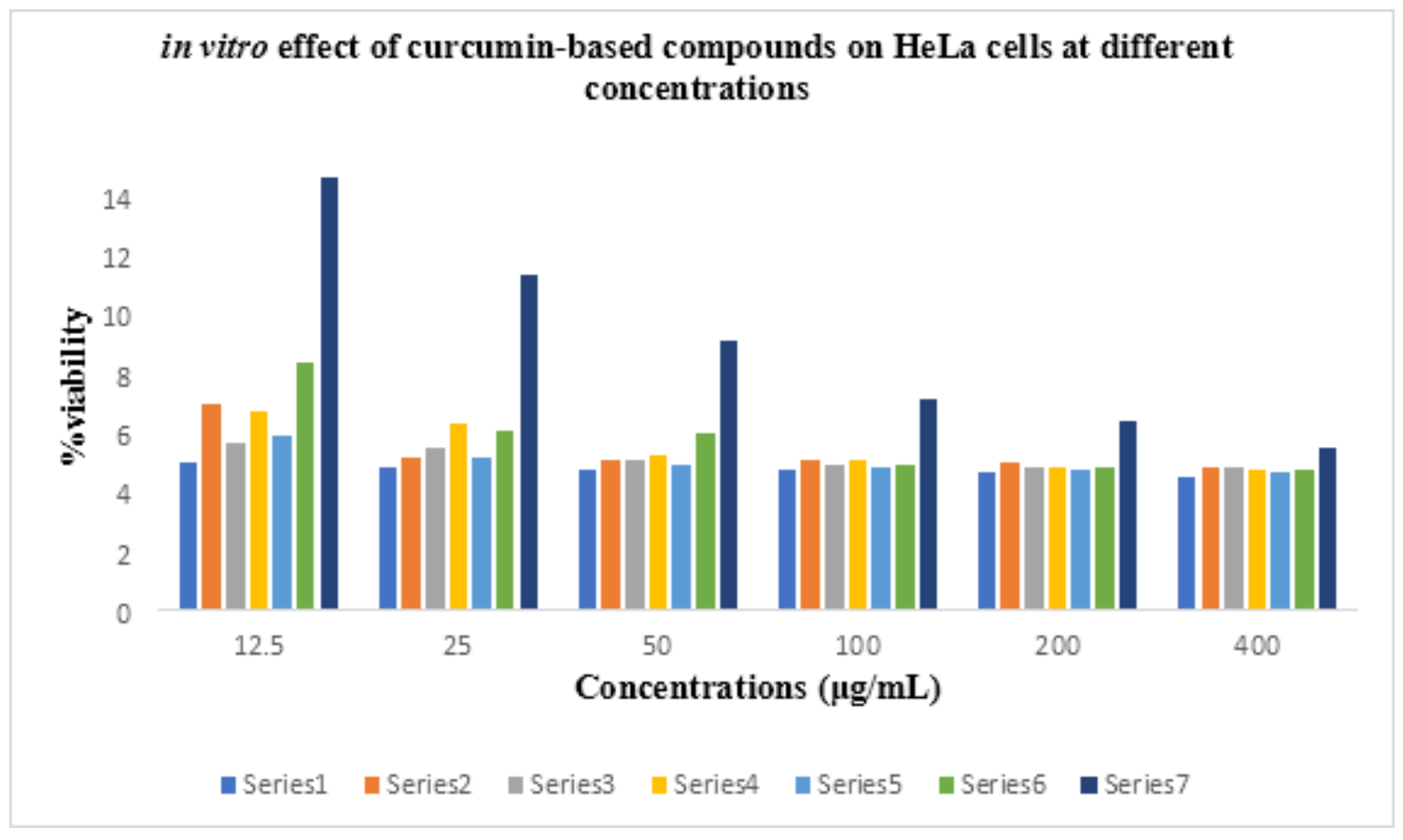

Figure 2 
In vitro effects of curcumin-based heterocyclics on HeLa cells at different concentrations $(\mu \mathrm{g} / \mathrm{ml})$.

Series 1: compound 2, series 2: compound 3 , series 3 : compound 4 , series 4 : compound 5 series 5 : compound 6, series 6: compound 7, series 7: compound 9.

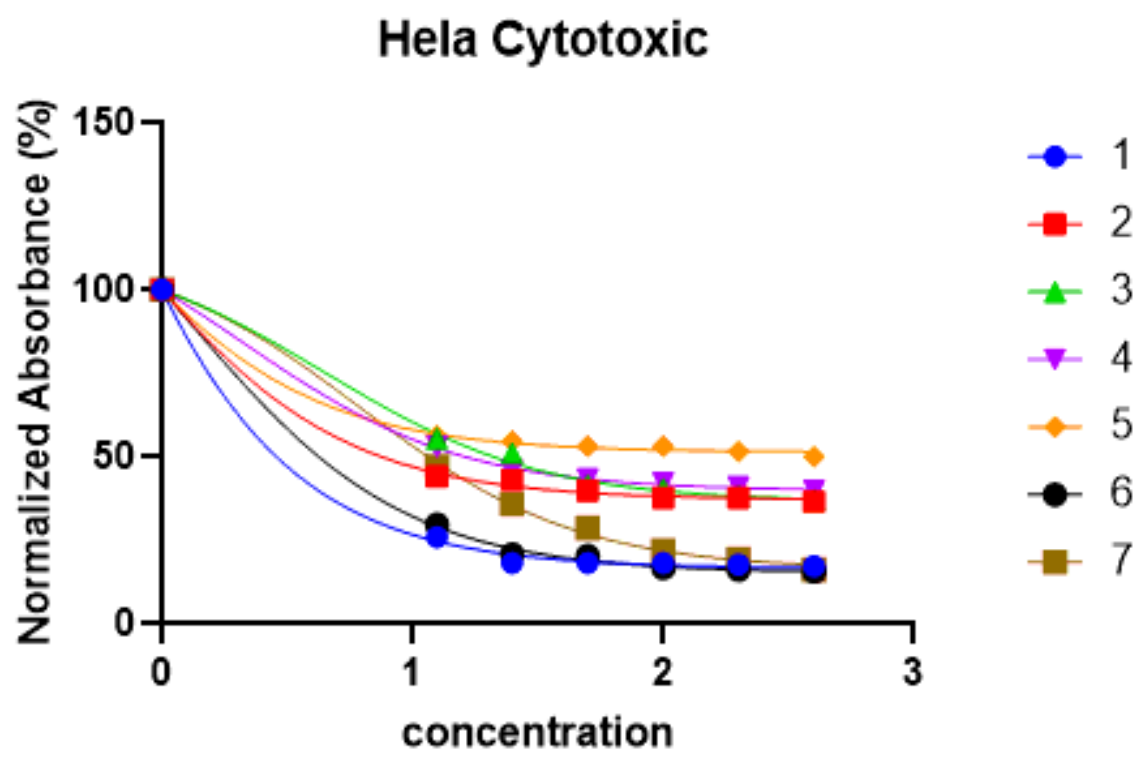

Figure 3

Cytotoxic effect of the prepared heterocycles on HeLa cancer cells.

Series 1 : compound $\mathbf{2}$, series 2 : compound $\mathbf{3}$, series 3 : compound $\mathbf{4}$, series 4 : compound $\mathbf{5}$ series 5 : compound 6, series 6: compound 7, series 7: compound 9.

Hela Cytostatic

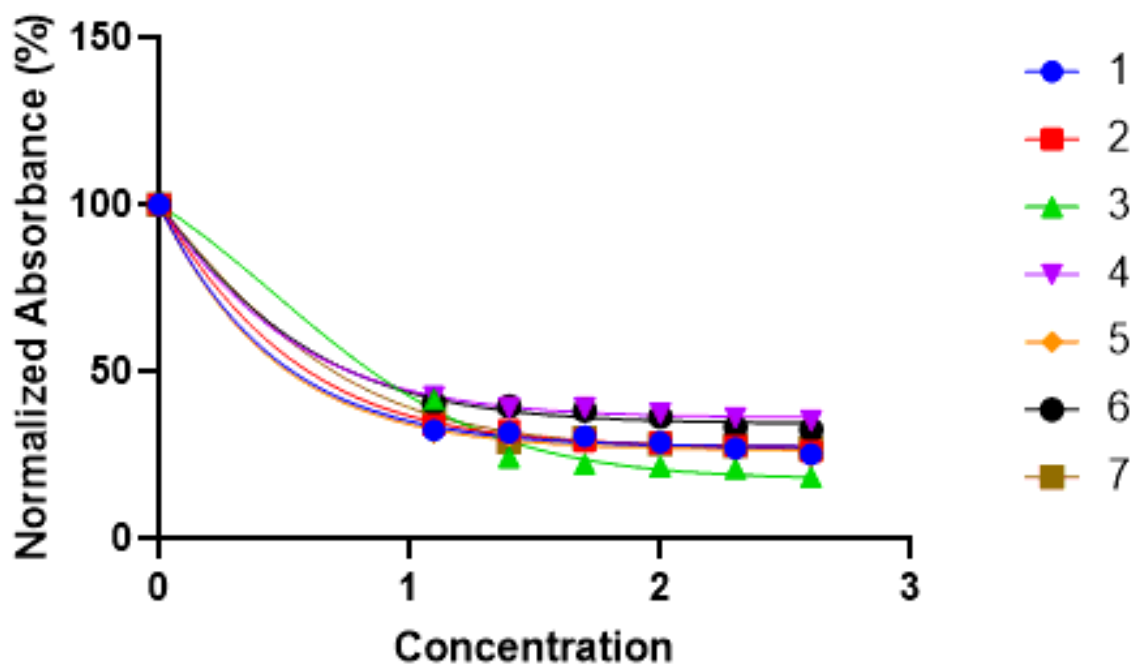


Figure 4

Cytostatic effect of the prepared heterocycles on HeLa cancer cells.

Series 1 : compound $\mathbf{2}$, series 2 : compound $\mathbf{3}$, series 3 : compound $\mathbf{4}$, series 4 : compound $\mathbf{5}$ series 5 : compound 6 , series 6 : compound 7 , series 7 : compound 9 .

L6 cytotoxic

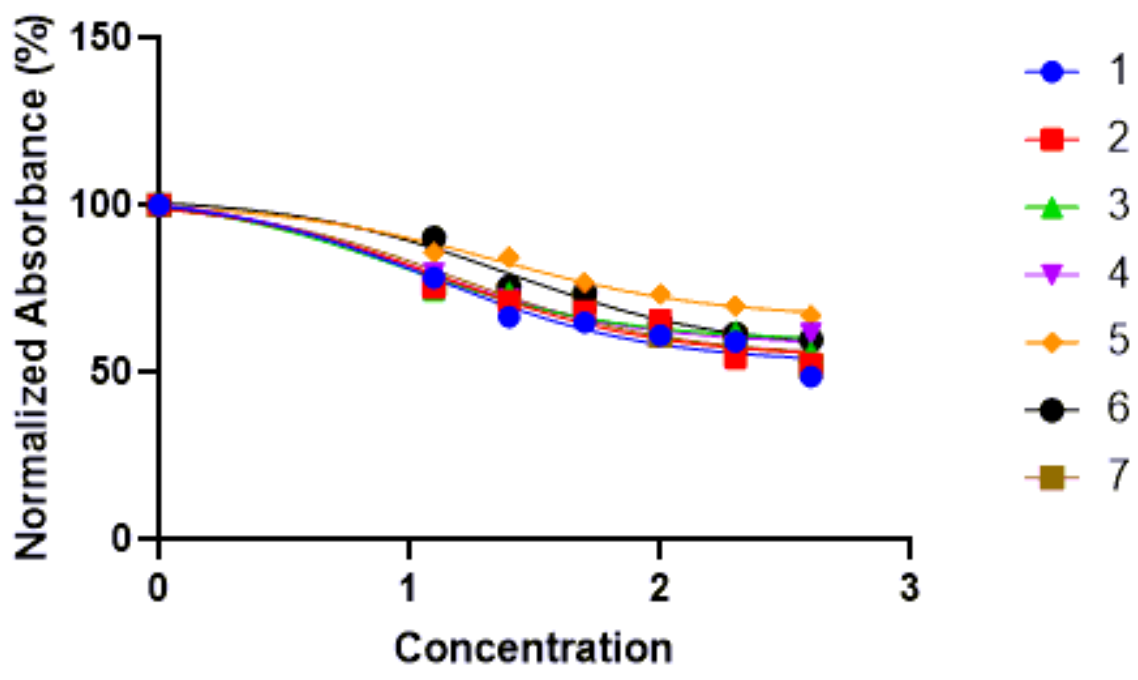

\section{Figure 5}

Cytotoxic effect of the prepared heterocycles on L6 Cells (normal cells).

Series 1 : compound $\mathbf{2}$, series 2 : compound $\mathbf{3}$, series 3 : compound $\mathbf{4}$, series 4 : compound $\mathbf{5}$ series 5 : compound 6 , series 6 : compound 7 , series 7: compound 9 . 


\section{L6 cytostatic}

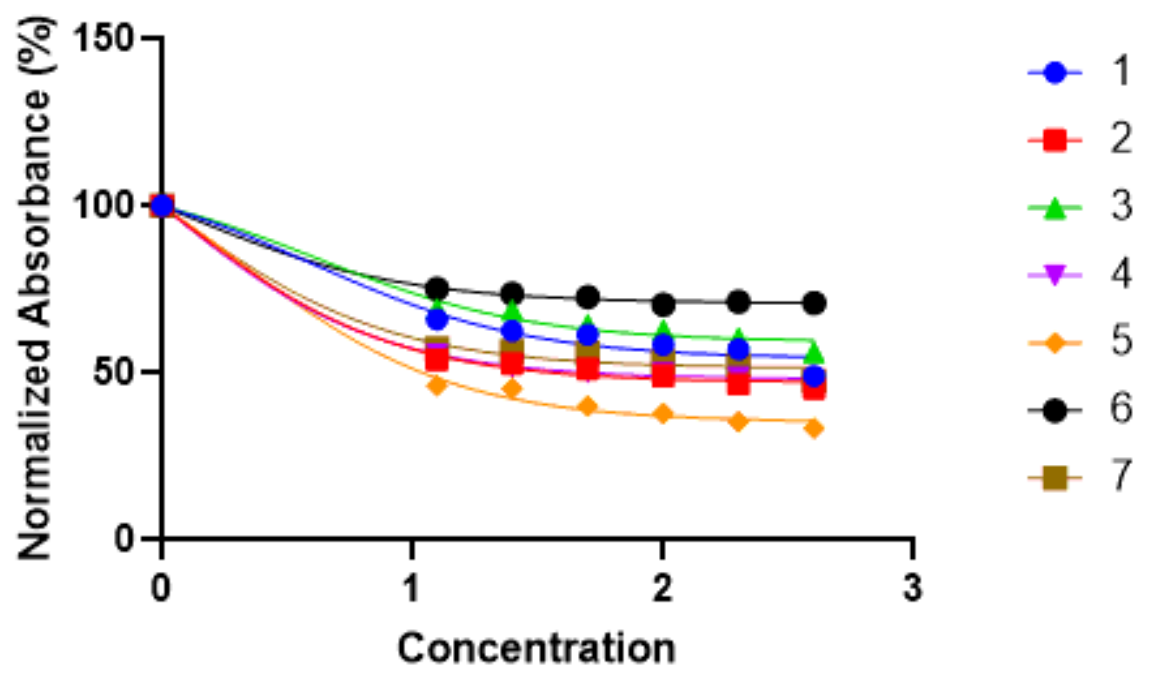

Figure 6

Cytostatic effect of the prepared heterocycles on L6 Cells (normal cells).

Series 1 : compound $\mathbf{2}$, series 2: compound $\mathbf{3}$, series 3 : compound $\mathbf{4}$, series 4 : compound $\mathbf{5}$ series 5 : compound 6, series 6: compound 7, series 7: compound 9 .
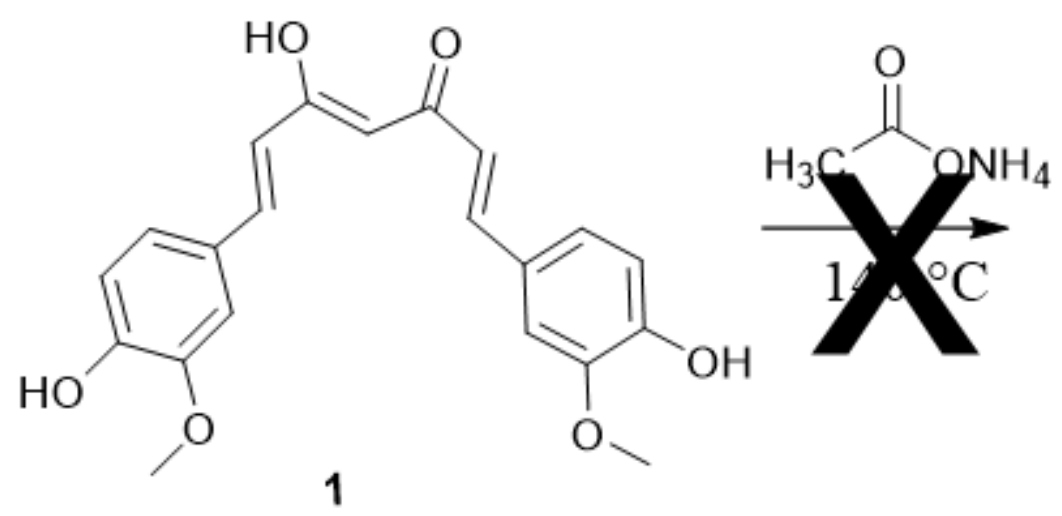

Figure 7

Reaction of curcumin with ammonium acetate

\section{Supplementary Files}

This is a list of supplementary files associated with this preprint. Click to download. 
- Scheme01.png

- Scheme02.png

- Scheme03.png

- Onlinefloatimage1.png 